\author{
Tomasz Jelonek \\ Uniwersytet Jagielloński \\ Wydział Polonistyki \\ ORCID: 0000-0002-4771-0021; e-mail: tomasz.jelonek@uj.edu.pl
}

\title{
Badania leksyki gwarowej w dobie przemian i globalizacji
}

\begin{abstract}
Akstrakt: Główny cel artykułu stanowi próba zarysowania problemów związanych z gromadzeniem leksyki gwarowej w dobie przemian językowo-kulturowych i globalizacji. W opracowaniu wykorzystano m.in. wnioski z eksploracji terenowej, którą autor prowadzi od roku $2011 \mathrm{w}$ gminie Wręczyca Wielka na północy województwa śląskiego w powiecie kłobuckim.

W pierwszej części tekstu omówiono pokrótce wpływ przemian cywilizacyjno-kulturowych i procesów globalizacyjnych na słownictwo mieszkańców współczesnej wsi. Przybliżono także specyfikę badań terenowych z pierwszej połowy XX w. W drugiej części przedstawiono natomiast trudności, na jakie napotyka współczesny badacz gwar. Zaproponowano również kilka rozwiązań metodologicznych, które mogą ułatwić gromadzenie materiału leksykalnego.
\end{abstract}

Słowa kluczowe: leksyka gwarowa, przemiany cywilizacyjno-kulturowe, procesy globalizacyjne, współczesna wieś, badania terenowe, badania dialektologiczne.

\begin{abstract}
Researches of subdialectal vocabulary in time of transformations and globalisation. The main purpose of this article is a description of research into subdialectal vocabulary in time of changes and globalization. The article contains conclusions of geographical research carried out by the author since 2011 in the area of Wręczyca Wielka community near Klobuck in the north of Silesia.

The first part of the article provides a short description of the impact of civilization and cultural transformations coupled with globalization processes on the vocabulary in the language spoken in rural areas. The specificity of field research from the first half of the $20^{\text {th }}$ century has also been shown. In the second part of the article, the author shows the difficulties faced by contemporary researchers and suggests a few methodological solutions which can simplify collection of the lexical material.
\end{abstract}

Keywords: subdialectal vocabulary, civilisation and cultural transformations, globalisation processes, contemporary rural areas, field research, dialectological research.

Jeden z najważniejszych elementów niematerialnego dziedzictwa kulturowego mieszkańców wsi tworzy słownictwo gwarowe. W dobie postępujących i niekontrolowanych przemian językowo-kulturowych oraz szerzącej się globalizacji badanie leksyki stanowi próbę uchwycenia reliktów lokalnych zwyczajów językowych. Prowadzenie rozległej eksploracji terenowej w XXI w. ma szczególne znaczenie na obszarach, na których gwara bezpowrotnie zanika (np. wsie w okolicach wielkich miast), a wcześniej nikt nie podjął się jej kompleksowego opisu. W takiej sytuacji wszelkie dane uzyskane od autochtonów są cenne dla dialektologa. Może on wówczas - przez rzetelną 
dokumentację faktów językowych - ocalić elementy szeroko pojętego dziedzictwa przodków i przyczynić się do upowszechnienia wiedzy na jego temat (zob. Karaś 2015).

Praca współczesnego dialektologa nie jest łatwa. Zdaniem Jerzego Reichana (1999, 265) „W ostatnich latach [...] zaczyna przypominać badania archeologa: jest to uciążliwe doszukiwanie się u najstarszych osób we wsi resztek gwarowego systemu". Trzeba jednak podkreślić, że trud badawczy rekompensuje nie tylko satysfakcja z poszerzenia stanu badań w zakresie danej gwary oraz przyczynek do jej ochrony i archiwizacji. Cenne jest również to, że $\mathrm{w}$ dobie poszukiwania własnego rodowodu, kultywowania silnych związków z lokalną wspólnotą istnieje zainteresowanie publikacjami stanowiącymi pokłosie badań terenowych. Praca dialektologa - oprócz wymiaru typowo naukowego - zyskuje ponadto wymiar społeczny. Jest potrzebna współczesnym mieszkańcom wsi, którzy w dobie globalizacji i unifikacji kultury coraz częściej przejawiają zainteresowanie m.in. słownictwem gwarowym, odzwierciedlającym kulturę ludową „małej ojczyzny” (por. Karaś 2015, 87), por. wypowiedź 53-letniej mieszkanki Truskolas na temat eksploracji prowadzonej przez autora: iag1 dobže že ktoś f koincu vźou śe za te naš teren i začyna oṕisyvać to co naše $\|^{2}$ fčeśńei to nigd ńe pisaủ.

Główny cel niniejszego opracowania stanowi przybliżenie specyfiki prowadzenia badań leksyki dyferencyjnej na początku XXI w., na obszarach, gdzie gwara zachowała się $\mathrm{w}$ niewielkim stopniu. $\mathrm{W}$ artykule omówiono m.in. trudności, na jakie napotyka badacz, oraz przedstawiono kilka propozycji metodologicznych, które mogą ułatwić gromadzenie słownictwa gwarowego we współczesnej wsi, w dobie przemian i globalizacji.

W opracowaniu wykorzystano m.in. wnioski z badań terenowych ${ }^{4}$, które autor prowadzi od roku $2011 \mathrm{w}$ gminie Wręczyca Wielka $\left(26\right.$ wsi) ${ }^{5}$ na północy województwa śląskiego ${ }^{6} \mathrm{~W}$ powiecie kłobuckim. Wspomniany region znajduje się $\mathrm{w}$ zasięgu występowania dialektu małopolskiego. Na podstawie eksploracji należy stwierdzić, że w języku mieszkańców gminy Wręczyca Wielka nie ma obecnie konsekwencji w zachowaniu cech gwarowych - nawet u najstarszych przedstawicieli mikrowspólnoty (Jelonek 2018a, 53). Elementy leksyki dyferencyjnej stanowią głównie bierny zasób słownictwa średniego i najstarszego pokolenia. Potwierdzają to obserwacje m.in. Haliny Karaś (2010), która pisze, że są takie obszary w Małopolsce, głównie w okolicach wielkich miast (np. Częstochowy), gdzie gwara zachowała się w niewielkim stopniu.

\footnotetext{
1 System fonologiczny i fonetyczny gwary gminy Wręczyca Wielka autor omówił w odrębnym opracowaniu, zob. Jelonek 2018a, 50-53.

2 Typy pauz w transkrypcji fonetycznej wprowadzono za Haliną Kurek (1979, 15-16).

3 Wszystkie cytaty gwarowe są autentycznymi wypowiedziami mieszkańców gminy Wręczyca Wielka. Zdecydowano się zapisać je fonetycznie, stanowią one bowiem przykład polszczyzny mówionej mieszkańców wspomnianej gminy. Zawierają fonetyczne i leksykalne cechy gwarowe.

${ }^{4}$ Pokłosie eksploracji stanowi m.in. Słownik mikrotoponimów gminy Wręczyca Wielka (zob. Jelonek 2018b), który rejestruje nie tylko nazwy obiektów fizjograficznych, lecz zawiera także obszerne konteksty kulturowe poszczególnych mikrotoponimów, wskazane przez respondentów. $23-41$.

5 Szerzej na temat gminy Wręczyca Wielka autor pisze w odrębnym opracowaniu, zob. Jelonek 2018a,

${ }^{6}$ Przed ostatnią zmianą podziału administracyjnego Polski, która miała miejsce 1 stycznia 1999 r., region ten należał do województwa częstochowskiego.
} 
$\mathrm{Na}$ temat językowo-kulturowych przemian polskiej wsi powstała do tej pory obszerna literatura. Zagadnienie to stało się przedmiotem badań m.in.: Mariana Kucały (1960), Zuzanny Topolińskiej (1990), Haliny Kurek (1995, 1998, 2003, 2006, 2010, 2012a, 2012b, 2014, 2018a, 2018b), Józefa Kąsia (1994), Haliny Pelcowej (1999, 2012, 2016, 2019), Haliny Kurek i Józefa Kąsia (2001), Renaty Kucharzyk (2001, 2002, 2012), Kazimierza Ożoga (2001, 2002, 2007), Heleny Grocholi-Szczepanek (2007, 2013) i Tomasza Kurdyły (2016). O specyfice prowadzenia badań gwarowych, w tym leksykalnych, w dobie przemian i globalizacji pisali m.in.: Halina Kurek (1997), Halina Pelcowa (1998, 2002), Józef Kąś (1999, 2001), Jerzy Sierociuk (2007), Helena Grochola-Szczepanek (2013), Justyna Kobus (2016) i Beata Ziajka (2019).

Postępujące zmiany cywilizacyjno-kulturowe przyczyniły się do tego, że współczesna wieś znacznie różni się od tej z pierwszej połowy XX w. W dawny obraz mikrowspólnoty wpisana była zawsze praca na roli, z którą wiązało się poszanowanie tradycji i kultywowanie religii. Mieszkańcy wiejskich wspólnot na co dzień posługiwali się gwarą i rzadko mieli kontakt z polszczyzną ogólną. Byli ponadto słabo wykształceni, nie mieli dostępu do elektryczności oraz środków masowego przekazu. Taki obraz wsi tkwi głównie w pamięci najstarszego pokolenia. Wielu przedstawicieli tej grupy społecznej ,żyje [...] w dwóch przestrzeniach socjosemantycznych - w tradycyjnej wiejskiej, która ustępuje, i w przestrzeni nowej, takiej samej jak w mieście, w cywilizacji współczesnej kultury konsumpcyjnej" (Ożóg 2001, 216). W wypowiedziach mieszkańców gminy Wręczyca Wielka pamięć o dawnej wsi łączy się z charakterystyką współczesnej cywilizacji, por.:

došu do tego že budyyki gospodarskíie iakíie byuy | inakịie byuy zagospodarovane | no to tak | popšerabínane to ịes | abo sobinie ktoź varštad zrobiu | abo garaže | abo to zostauo rozebrane || na f'si to sưm tero tyko ṕieskí inorki | takíie ozdobne | ne kundle | ṕieskí sưm barzo šanovane | barzo śe tym ṕieskům povoźi | natomiast ńi ma žodnego zv́iežyńća gospodarskíigo | ńi ma ter obůr staińi xlyvůf kurńikůf || na podvůrkax to ies tero kostka | elegancko vykostkovane | o | sům inakíneś kševy unozdobne | travńiki || no dovńii krova vyiaduna na podvưrku | a źiśei śe frysyko mašynkům goli | kośarkům

(mężczyzna, lat 74, Truskolasy ${ }^{7}$ );

teros to ịuž na podvưrku ńi gaźiny ńe čymo | v ogůle ńi ma žodnyi gaźiny | teroz ńe śmier źi gnoiym | kura ne byźe po kostce pšeće paradovać | nasrauaby i zabruźina | na podvi̊rkax teroz ies čysto barzo | luźe dbaiiom o to | mainim uadne puoty s klinkíieru a ńe ze štaxyt | gŕil stoi $\mid$ ležak· $i$ parasole | podvurko ći proịektand užunzo

(mężczyzna, lat 80, Truskolasy);

tu śe źéci xuśtauy | bapki śe zešuy | sůmśatki śeźauy śṕiyvauy | tyn grou | tu śe xuśtali | byuo vesouo | biyda byu ale byuo vesouo || a teros tyn mo to tyn mo tamto | tyn mo meble takíie | tyn ovakíe | tyn mo dyvan i gźeź no to co śe pšežyuno | pšećež víadìmo krova byua

${ }^{7} \mathrm{~W}$ nawiasie podano miejscowość, w której odnotowano cytat. 
di̊m v dům | kozy byuy | śf'ińe | śf'ińe byuy $i$ v́iadůmo || na cornym zuže vyxovany iez a potym bo mu krova śmierźzi

(kobieta, lat 81, Kuleje).

Szeroko pojęte przemiany, jakie wciąż zachodzą na obszarach wiejskich, znajdują odzwierciedlenie w słownictwie. Do zasobu leksykalnego mieszkańców wsi, nawet tych najstarszych, oprócz nazewnictwa ogólnopolskiego wkraczają wyrazy, zwroty i wyrażenia związane z nową techniką, kulturą konsumpcyjną i globalizacją, por.:

pańe tomku | iagby pan xćau to možemy tež na skeiṕie porozmavíiać || ia mam laptopa $v$ domu | ía umiem bo ia ze synem z ayglịi čxsto rozmav́iam \| podam panu sfưi loǵin | pan mńe znaiźe bo ia ńe umiem vyšukać || mam kamerke mikrofon | mama moia uśunńże i možna rozmav́iać ${ }^{8}[\ldots]||$ do viźeńa | žyče panu miuego úikendu

(kobieta, lat 66, Wręczyca Mała);

teros to te kobiyty iuš sưm i.ne || my to byuy takkie starodovne kobiyty | za gospodarküm | za tym | robiun śe žeby byuo i žeby źeći míniuy co ineś $\|$ a tero to pańe žebyś pan robiu i uninyi dou $\mid$ tak | tyi co pan xoźiž do ńii | žebyź iyyi dou | to tak | a tiag ìyi ne doš to pana vygưní f ṕieriny || tero sům i.ne kobiyty | uniny kcum tero xuopa takigo co by robiu a ữna sé upudrovana umalovana $i$ kinnec | $i$ śeźana inak pańi || pańe tag ịag inž my robiuy to in kobiy. takiy ńe byńźe | ńe byńźe inuš | a tero to kobiyta pačy xuopa vykožystać | žeby xuob mín dužo ṕiynynzy | auto uadne | do resteurac'in i̊im brou | do kav́iarńi || tero to kobiyty f polu ńe byndìm robiż bo by śe im tipsy pouomauy

(kobieta, lat 95, Hutka);

můi bože | tero to kobiyty dbainim o śebín | ne tag inag dovńii $\mid$ do fryz’iera xoźzi $\mid$ do kosmetyčki xoźi | na paznokće xoźi| brv́i se zrob. i iešče śe otxuzo bo za grůbo | na auerobikí inakíeś xoźi

(kobieta, lat 82, Hutka).

Zdaniem Józefa Kąsia (1999, 60) „płaszczyzna leksykalna jest tą płaszczyzną systemu języka, na której powojenne przeobrażenia gwar dokonują się najszybciej i są najłatwiej postrzegane. Wynika to z najmocniejszego związku tego właśnie podsystemu z rzeczywistością pozajęzykową". Przeobrażenia słownictwa, jakim posługują się współcześni mieszkańcy wsi, stanowią wynik dwu uzupełniających się procesów. Do zasobu leksykalnego, oprócz nazewnictwa ogólnopolskiego, przenikają obecnie jednostki odzwierciedlające przemiany społeczno-kulturowe i procesy globalizacyjne. Z drugiej strony, w związku z zanikiem wielu desygnatów gwarowych, technicyzacją i wszechobecną nobilitacją polszczyzny ogólnej, następuje zanik słownictwa dyferencyjnego (Kąś 1999, 60-61). Dynamika zmian w leksyce jest już widoczna nie tylko na obszarach wiejskich, które sąsiadują z dużymi miastami (por. Żebrowska 2017, 238), lecz także w tych regionach Polski (np.: Podhale, Orawa, Spisz), które do tej pory

\footnotetext{
${ }^{8}$ W cytacie mowa o respondentce urodzonej w $1921 \mathrm{r}$.
} 
zachowywały i pielęgnowały swoją kulturową odrębność (Grochola-Szczepanek 2013). Postępująca urbanizacja polskiej wsi z pewnością nie ułatwia badania leksyki gwarowej. Współczesne zmiany leksykalne stanowią złożony problem, który należy rozpatrywać ,z punktu widzenia zmian systemowych oraz funkcjonowania słownictwa gwarowego i niegwarowego (w uproszczeniu ogólnopolskiego) w zróżnicowanych sytuacjach komunikacyjnych" (Kąś 1999, 60; por. Pelcowa 2002, 390-392). Postulowany przez badacza dwuaspektowy opis zmian w systemach leksykalnych gwar nie jest zadaniem łatwym do wykonania, współczesny dialektolog już bowiem na etapie gromadzenia materiału badawczego napotyka na duże trudności.

Uwarunkowania społeczno-kulturowe współczesnej wsi oraz zmiany w mentalności jej mieszkańców powodują, że metody i techniki badań dialektologicznych wypracowane w pierwszej połowie XX w. ${ }^{9}$ często są już niewystarczające. Specyfikę tradycyjnej eksploracji z lat pięćdziesiątych XX w., której pokłosie stanowi Atlas językowy kaszubszczyzny i dialektów sąsiednich (AJK), dobrze ilustrują wspomnienia Ewy Rzetelskiej-Feleszko (1997, 40):

W badaniach posługiwaliśmy się własnym „kaszubskim” kwestionariuszem liczącym około dwóch tysięcy pytań [...]. Bardzo dużą wagę przywiązywaliśmy do właściwego doboru badanej wsi i informatorów. Wieś musiała być w znacznej większości zamieszkana przez rodziny z dawna $\mathrm{w}$ niej osiadłe, powinna być położona $\mathrm{w}$ pewnej odległości od większych miast i ważnych linii kolejowych (chodziło o możliwie słabe kontakty zawodowe mieszkańców z ośrodkami, które mogły wpływać na zmiany zachodzące w gwarze). Informatorzy musieli być starsi [...], inteligentni, z dobrą dykcją, urodzeni i - w miarę możliwości mieszkający przez całe życie w danej wsi. Taki dobór badanej wsi i informatorów gwarantował jednolitość metodologiczną całego atlasowego obszaru oraz uzyskanie obrazu gwary jak najmniej zmienionego pod wpływem polszczyzny ogólnej i czynników cywilizacyjnych.

Podobne zasady prowadzenia badań terenowych towarzyszyły także twórcom innych atlasów językowych (AGP, AJPP, MAGP). Postępująca globalizacja oraz zmiany W wiejskiej obyczajowości spowodowały, że współczesny dialektolog, chcąc zgromadzić materiał leksykalny, musi dostosować metodologię pracy w terenie do specyfiki współczesnej wsi i jej mieszkańców.

W XXI w. zasadniczy problem badaczy gwar stanowi trudność w nawiązaniu kontaktu z potencjalnymi respondentami. Wsie w okolicach wielkich miast są często wyludnione. Większość mieszkańców czynnych zawodowo i uczniów szkół średnich w ciągu dnia przebywa w pobliskim mieście, a rodzinną miejscowość traktuje jako „noclegownię” (Żebrowska 2017, 238). Nawiązanie relacji z osobami starszymi, szczególnie autochtonami jest zatem często kłopotliwe, a niekiedy wręcz niemożliwe. Barbara Żebrowska $(2017,238)$ na podstawie doświadczeń z badań dialektologicznych prowadzonych w okolicach Krakowa pisze, że „osoby starsze, nauczone (nie bez przyczyny) współczesnej nieufności, często boją się przyjmować obcych w domu nawet po rekomendacji przez kogoś znajomego, nawet miejscowego proboszcza" (Żebrowska 2017, 238). Próba pozyskania informatorów kończy się często po identyfikacji

\footnotetext{
${ }^{9}$ Szerzej na ten temat pisał Alfred Zaręba (1955) w artykule $O$ metodach i technice badań gwarowych.
} 
eksploratora przez domofon. Badacz gwar jest zazwyczaj utożsamiany przez mieszkańców wsi z natrętnym ankieterem, który zadaje dużo pytań, a jego praca - według członków wiejskich mikrowspólnot - jest bezproduktywna. Aby pozyskać respondentów do badań, eksplorator powinien - po uprzednim wylegitymowaniu się odpowiednim dokumentem (np.: legitymacją służbową, zaświadczeniem wydanym przez promotora, informującym o zbieraniu materiału badawczego do pracy licencjackiej/magisterskiej/doktorskiej) - nawiązać kontakt z sołtysami, wójtami, proboszczami, miejscowymi nauczycielami, leśniczymi, a także kołami gospodyń wiejskich, zespołami regionalnymi, ochotniczymi strażami pożarnymi czy pracownikami instytucji kultury. Interesująca prezentacja celu badań, które prowadzi dialektolog, może przyczynić się do pozyskania informatorów już spośród wymienionych osób. Przedstawiciele organizacji społecznych, kulturalnych i oświatowych mogą także wskazać najstarsze osoby we wsi, z którymi warto nawiązać kontakt, i - przede wszystkim - zaanonsować przybycie dialektologa lub nawet towarzyszyć mu podczas przeprowadzania wywiadu. Zapowiedź wizyty badacza przez osobę powszechnie znaną we wsi zmniejsza nieco dystans społeczny i zwykle gwarantuje to, że próba nawiązania kontaktu nie zakończy się podczas krótkiej rozmowy przy furtce.

Jak już wspomniano, współcześni mieszkańcy wsi są bardzo nieufni względem osób, które nie są autochtonami. Nawet zapowiedź wizyty osoby trzeciej przez innego mieszkańca nie zapewnia możliwości swobodnej rozmowy. Społeczność mikrowspólnoty, szczególnie ta najstarsza, jest świadoma różnego rodzaju zagrożeń (np. kradzieży, włamań), przed którymi przestrzegają środki masowego przekazu. Niektórzy mieszkańcy wsi - w ramach działalności klubów seniora czy lokalnych uniwersytetów trzeciego wieku ${ }^{10}$ - biorą udział $\mathrm{w}$ różnego rodzaju pogadankach organizowanych przez policję. Głównym celem takich spotkań jest wzmożenie czujności i ostrzeżenie osób starszych przed czyhającymi na nie niebezpieczeństwami, w tym nieznajomymi osobami, np. potencjalnymi eksploratorami. Biorąc pod uwagę współczesne uwarunkowania społeczno-kulturowe, uznać trzeba, że z najlepszym rozwiązaniem mamy do czynienia wówczas, kiedy dialektolog jest autochtonem prowadzącym badania $\mathrm{w}$ obrębie regionu, z którego się wywodzi. W takiej sytuacji miejscowa społeczność identyfikuje eksploratora jako mieszkańca wsi (por. tomůśs | ty iesteź z našei ulicy | ty înesteź naš | my će od źecka znamy i ći pomožemy), a jeśli go bezpośrednio nie zna, utożsamia z przedstawicielami konkretnej rodziny (por.: a | ty iesteź od inuzka ielůnka z dymbiececnyin; ty

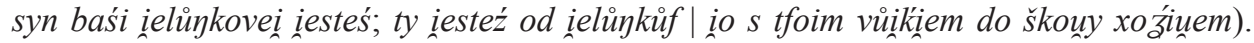
Jeżeli eksplorację prowadzi grupa dialektologów, warto zadbać o to, aby chociaż jedna osoba spośród nich była identyfikowana przez lokalną społeczność jako mieszkaniec regionu. Wówczas ułatwi ona nie tylko dostęp do potencjalnych informatorów, ale może też wprowadzić pozostałych badaczy w realia społeczno-kulturowe danej wsi.

Rola dialektologa-autochtona nie ogranicza się tylko do ułatwienia pozyskania potencjalnych informatorów. Wspomniany eksplorator ma także korzystny wpływ na

\footnotetext{
${ }^{10}$ Na przykład w gminie Wręczyca Wielka (gmina wiejska) funkcjonuje Wręczycka Akademia Seniora, która integruje mieszkańców powyżej 60. roku życia. W ramach działalności Akademii seniorzy uczą się m.in. języka angielskiego, obsługi komputera i tabletu, a ponadto aktywnie spędzają czas podczas wspólnych treningów nordic walking lub wycieczek krajoznawczych.
} 
przebieg badań i jakość gromadzonych materiałów. Może on bowiem analizować gwarę obecną w środowisku domowo-rodzinnym, ponieważ nie jest traktowany przez swoich rozmówców jako przedstawiciel innego kręgu kulturowego, np. miejskiego (zob. Kurek 1994). Helena Grochola-Szczepanek $(2006,26)$ zwraca uwagę na to, że

osoba badacza nieznana mieszkańcowi wsi, będąca reprezentantem innej kultury, tzw. miejskiej i innego języka, nie wzbudza zaufania badanego. Rozmówca w takiej sytuacji próbuje wykluczyć z użycia swój kod gwarowy i przejść na kod osoby prowadzącej rozmowę, co wpływa niekorzystnie na wynik badania. [...] nieznajomość gwary i kultury danego regionu przez osobę badającą może wpłynąć [też - T.J.] na pewne nieporozumienia językowe czy wręcz niewłaściwą interpretację pewnych faktów językowych i kulturowych.

W trakcie prowadzenia eksploracji przez dialektologa-autochtona zostają ograniczone problemy związane $\mathrm{z}$ negatywnym wartościowaniem gwary oraz nieznajomością uwarunkowań historyczno-kulturowych. Eksplorator jest postrzegany jako przedstawiciel tej samej mikrowspólnoty, do której należy badana społeczność.

Karol Dejna we Wstępie do I tomu Atlasu gwar polskich (AGP) pisze, że „do połowy naszego stulecia eksplorator miał możność [...] poznania systemu językowego badanej gwary w toku rozmowy z każdym prawie mieszkańcem wioski” (AGP I, 8). We współczesnej wsi odpytywanie przypadkowych respondentów, którzy wyrażą zgodę na przeprowadzenie wywiadu, może prowadzić do uzyskania niepełnych bądź zafałszowanych wyników eksploracji. Aby zbadać „resztki gwarowego systemu” w danej miejscowości, trzeba zadbać przede wszystkim o właściwy dobór respondentów. Na obszarach w okolicach wielkich miast, gdzie gwara zachowała się bardzo słabo, należy pozyskać - w miarę możliwości - jak najstarszych informatorów, którzy w ciągu całego życia nie byli zbyt mobilni. W badaniach trzeba uwzględnić czynniki socjolingwistyczne, m.in. wiek i płeć respondenta, jego wykształcenie, pochodzenie i status społeczny, informacje na temat ewentualnej pracy zawodowej w mieście oraz dane o koligacjach rodzinnych (Dunaj 1986, 20; Pelcowa 1998). Warto szukać takich informatorów, którzy całe życie spędzili w badanej wsi i nie uwikłali się w żadne związki (np. małżeństwo) z przedstawicielami pobliskich lub odległych regionów. Uwzględnienie tego typu parametrów w trakcie doboru respondentów podnosi nie tylko jakość i rzetelność prowadzonych badań gwarowych, ale pozwala także uniknąć zarejestrowania przez dialektologa słownictwa, które nie należy do systemu leksykalnego danej wsi, a zostało przyniesione wraz z migracjami ludności.

Oprócz prawidłowego doboru respondentów badacz leksyki gwarowej powinien również zadbać o własne, gruntowne przygotowanie do rozmowy $z$ informatorami. Rozpoczęcie badań dialektologicznych należy poprzedzić przestudiowaniem literatury z zakresu historii i kultury regionu, na którym zaplanowano eksplorację. Warto też, w kontekście wspomnianej współpracy z organizacjami kulturalno-oświatowymi, poprosić o dostęp do źródłowych materiałów rękopiśmiennych, np. kronik kół gospodyń wiejskich, zespołów regionalnych, OSP i szkół. Wnikliwa lektura tego typu materiałów wskaże te elementy wiejskiej obyczajowości, które dla mieszkańców eksplorowanego regionu są szczególnie ważne. Pozyskane informacje należy uwzględnić w planowaniu tematyki rozmowy $\mathrm{z}$ informatorem. Przy doborze zagadnień do wywiadu warto 
zapoznać się ponadto z opracowaniem Ludwika Stommy (1975) pt. Stan badań nad obrzędowościa polska od połowy XVIII w. Część I. Analiza statystyczna bazy materiałowej $^{11}$. We wspomnianym artykule badacz przedstawia liczbę odnalezionych opisów obrzędów (np. zwyczajów związanych z narodzinami i śmiercią, weselami, zapustami, ostatkami, adwentem) w poszczególnych regionach etnograficznych Polski. Opracowanie Stommy stanowi dobrą wskazówkę do prowadzenia badań leksyki związanej z obrzędowością. Na jego podstawie można łatwo stwierdzić, o które zwyczaje warto pytać respondentów w trakcie eksploracji.

W dobie przemian językowo-kulturowych i postępującej globalizacji należy zadbać o to, aby badania leksyki gwarowej miały charakter dwuetapowy (por. Jelonek 2018a, 19). Celem pierwszej wizyty u informatora jest przede wszystkim nawiązanie swobodnego kontaktu $\mathrm{z}$ respondentem. Dialektolog $\mathrm{w}$ trakcie takiego spotkania powinien w przystępny dla mieszkańca wsi sposób - określić cel swojej wizyty oraz przedstawić tematykę dotyczącą przedmiotu jego zainteresowań. Ponieważ leksyka dyferencyjna stanowi głównie bierny zasób słownictwa, informator musi mieć czas, by z pokładów pamięci przywołać interesujące badacza słownictwo gwarowe ${ }^{12}$. Ograniczenie eksploracji do jednego spotkania z respondentem wpływa niekorzystnie na samego informatora, który często denerwuje się, że nic nie pamięta, por. î to xyba ńic panu ńe povíiem | bo io ńiz ńe pamiunntům || starśi ody mńe to by víeźeli. Kolejna wizyta u autochtona - po wcześniejszym ustaleniu z nim terminu - powinna odbyć się za kilka lub kilkanaście dni od momentu pierwszego spotkania. Badacz gwar musi w taki sposób prowadzić rozmowę, aby odpytywanie respondenta nie zakłóciło swobodnej i nieoficjalnej atmosfery (por. Kobus 2016, 335). Jeśli mieszkaniec wsi wyrazi zgodę, warto utrwalić jego wypowiedzi za pomocą rejestratora cyfrowego. Dialektolog powinien jednak ocenić, w jaki sposób propozycja nagrania zostanie odebrana przez respondenta. Jeśli nie jest on zbyt przychylny do tego typu działań, lepiej nie proponować użycia dyktafonu, ponieważ chęć zarejestrowania rozmowy może wpłynąć negatywnie na jakość badań, np. mieszkaniec wsi będzie unikał kodu gwarowego lub nawet poprosi o zakończenie spotkania. Należy pamiętać o tym, aby nie przyspieszać procesu odpytywania i każdemu respondentowi pozwolić wypowiedzieć się na różne tematy nawet te, które nie stanowią przedmiotu badan. Umiejętność prowadzenia rozmowy ze starszymi ludźmi oraz chęć słuchania ich opowieści umożliwią - w trakcie długich monologów mieszkańców wsi - dopytanie o te kwestie, które dla badacza są szczególnie interesujące. W zależności od przedmiotu badań (np. leksyka związana z pracą na roli) i typu informatora ${ }^{13}$ należy zastosować odpowiedni kwestionariusz leksykalny lub prowadzić rozmowę tematyczną. Jeśli pytania $\mathrm{z}$ kwestionariusza wprowadzają respondenta $\mathrm{w}$ zakłopotanie i nie potrafi on udzielić na nie odpowiedzi, warto automatycznie przejść do swobodnej rozmowy na interesujący badacza temat, aby nie zniechęcić respondenta do dalszej części badań. Podczas wywiadu dobrze jest mieć ze sobą zdjęcia

11 Informacje bibliograficzne na temat wspomnianego artykułu przekazała autorowi Pani dr hab. Barbara Grabka, prof. IJP PAN, za co autor składa serdeczne podziękowania.

12 Warto poprosić także informatora o to, aby słowa, które sobie przypomni, zapisywał.

13 O typach informatorów ze względu na sytuację komunikacyjną i przełamywanie barier pisała m.in. J. Kobus (2016, 333-335). 
lub ryciny interesujących eksploratora desygnatów. Ich prezentacja może bowiem pomóc w gromadzeniu materiału leksykalnego (por. Kobus 2016, 335).

Zdaniem Grocholi-Szczepanek $(2006,34)$

wywiad indywidualny daje lepsze wyniki przy zagadnieniach drażliwych lub krępujących uczestnika przed „otwarciem się” w grupie. Poza tym jest to metoda łatwiejsza technicznie do przeprowadzenia oraz do interpretacji danych z nagrania (wypowiedzi jednego rozmówcy). W trakcie badania tą metodą badacz ma szanse poznać dogłębnie opinie, skojarzenia i wypowiedzi jednego rozmówcy.

Przemiany języka i kultury polskiej wsi powodują jednak, że indywidualny wywiad z respondentem nie zawsze jest wystarczający. Dane uzyskane od jednego mieszkańca mikrowspólnoty warto skonfrontować z informacjami zgromadzonymi podczas wywiadów grupowych. Założenia metodologiczne tego typu wywiadów oraz ich przydatność do badań leksyki gwarowej szczegółowo omówiła wspomniana badaczka w artykule pt. Badania fokusowe mowy mieszkańców wsi (Grochola-Szczepanek 2006). Zastosowanie metody fokusowej wymaga uprzedniego zaplanowania spotkania grupy mieszkańców. Do tego typu przedsięwzięcia warto wykorzystać na przykład zebrania kół gospodyń wiejskich lub posiedzenia kół emerytów, rencistów i inwalidów. W zmieniającej się rzeczywistości wiejskiej można nawiązać również współpracę z lokalnymi uniwersytetami trzeciego wieku, które funkcjonują nie tylko w miastach, lecz także coraz częściej przy wiejskich ośrodkach kultury. W trakcie dyskusji na dany temat mieszkańcy wsi wzajemnie się uzupełniają, a wspólne „rozmowy [...] stymulują uczestników do większej aktywności, co skutkuje pojawieniem się opinii, skojarzeń i sformułowań, które zwykle nie występują w rozmowie z jednym rozmówcą. Dzięki temu otrzymuje się bogaty i różnorodny materiał" (Grochola-Szczepanek 2013, 50).

Eksplorator, który zajmuje się badaniem słownictwa dyferencyjnego, powinien pamiętać także o tym, że leksyka gwarowa stanowi odzwierciedlenie ludowej wizji świata. Użycie danej nazwy, która nie ma odpowiednika w języku ogólnym, może być podyktowane tradycją danej wsi lub wynikać z kontekstu kulturowego. „Nie wystarczy [sama - T.J.] znajomość słowa, ale należy poznać jego strukturę, uwikłania kontekstowe i charakter nazywanego desygnatu: do czego służy (np. jest przedmiotem, zjawiskiem, całością lub częścią czegoś, jaki ma kształt, kolor, jaką pełni funkcję, dlaczego używa się nazwy i przedmiotu, kto używa, w jakiej sytuacji)" (Pelcowa 2011, 126). Dopiero uwzględnienie w badaniach leksykalnych wymienionych postulatów gwarantuje prawidłowe odczytanie i zrozumienie ludowej wizji świata zakrzepłej w słownictwie.

Na koniec warto również wspomnieć o tym, że współczesny mieszkaniec wsi, który wyrazi zgodę na rozmowę z eksploratorem, jest często zainteresowany wynikiem prowadzonych badań. Respondent niejednokrotnie oczekuje od dialektologa informacji na temat tego, gdzie zostaną opublikowane zgromadzone materiały. Chęć zapoznania się członków wiejskich mikrowspólnot z rezultatami eksploracji ma zazwyczaj dwojaką motywację. Z jednej strony wynika ze wspomnianego już podkreślenia związków z „małą ojczyzną" i potrzebą wzbogacenia szeroko pojętej wiedzy na jej temat, a $\mathrm{z}$ drugiej - jest podyktowana zamiarem późniejszego pochwalenia się w lokalnym 
środowisku informacją o publikacji, w której wykorzystano wypowiedzi informatora (kryterium prestiżu). Współczesny dialektolog musi mieć świadomość tego typu uwarunkowań społeczno-kulturowych. Aby podtrzymać kontakt z gronem informatorów w celu prowadzenia nowych eksploracji, powinien on udostępnić zainteresowanym mieszkańcom oraz instytucjom kulturalno-oświatowym wyniki swoich badań ${ }^{14}$. Warto również zadbać o to, aby informator miał stały kontakt z eksploratorem, np. przez wymianę numerów telefonów. Z doświadczeń badań terenowych, które prowadzi autor, wynika, że niektórzy respondenci przez długi czas od przeprowadzenia wywiadu wracają do spotkania z badaczem gwary. Często przypominają sobie nowe nazwy, które nie zostały omówione podczas rozmowy z eksploratorem. Niektórzy mieszkańcy wsi odczuwają potrzebę podzielenia się tego typu informacjami z badaczem. Stały kontakt $\mathrm{z}$ informatorem jest również cenny dla eksploratora. Podczas ewentualnych problemów z analizą materiału leksykalnego i brakiem bezpośredniego dostępu do informatorów (np. w dobie pandemii) może on poprosić autochtona o krótką konsultację telefoniczną.

Problematyka badań leksyki gwarowej w dobie przemian i globalizacji została W niniejszej pracy jedynie zasygnalizowana. Dynamicznie zmieniająca się rzeczywistość językowo-kulturowa polskiej wsi wymaga nie tylko opracowania nowego instrumentarium badawczego, lecz także sposobu opisu zróżnicowania języka mieszkańców współczesnych mikrowspólnot (Grochola-Szczepanek 2013, 51). W pierwszej kolejności należy badać wsie w okolicach wielkich miast, w których do tej pory nie prowadzono eksploracji. Jest to ostatni moment, aby na podstawie rozmów z najstarszymi przedstawicielami lokalnych społeczności odnotować leksykalne i fonetyczne cechy gwarowe. Badanie słownictwa dyferencyjnego w XXI w. wymaga nie tylko dobrego przygotowania teoretycznego w zakresie podstaw dialektologii i specyfiki kultury ludowej danego regionu. Należy wykazać się również dużą determinacją w poszukiwaniu respondentów. Później z kolei w taki sposób trzeba poprowadzić rozmowę, aby na podstawie wypowiedzi informatora zrekonstruować „zamknięty w języku stary świat” (Pelcowa 2009, 97).

\section{Bibliografia}

AGP (1998-2002), Atlas gwar polskich, t. I: Dejna K., Małopolska, t. II: Dejna K., Gala S., Zdaniukiewicz A., Czyżewski F., Mazowsze, t. III: Dejna K., Gala S., Śląsk, t. IV: Dejna K., Wielkopolska, Kaszuby, Warszawa.

AJK (1964-1978), Atlas językowy kaszubszczyzny i dialektów sąsiednich, oprac. przez Zespół Zakładu Słowianoznawstwa PAN w Warszawie, t. I-VIII kier. Z. Stieber, t. IX-XV kier. H. Popowska-Taborska, Wrocław-Warszawa-Kraków-Gdańsk.

\footnotetext{
14 Warto zatem przemyśleć kwestię zapisu cytatów gwarowych w postaci transkrypcji fonetycznej. Mieszkańcy wsi mają duże trudności z odczytaniem tekstów we wspomnianej formie, o czym przekonał się sam autor po przedstawieniu wyników eksploracji informatorom z gminy Wręczyca Wielka, por. io to xćou pšečytać coź naṕisou | ale to po x’inisku xyba naṕisane | same značkí x’înskíle.
} 
AJPP (1934), Małecki M., Nitsch K., Atlas językowy polskiego Podkarpacia, cz. 1-2, Kraków [cz. 1: 500 map; cz. 2: Wstęp, objaśnienia, wykazy wyrazów].

Dunaj B. (1986), Dialektologia a socjolingwistyka, „Acta Universitatis Lodziensis. Folia Linguistica” XII, s. 15-23.

Grochola-Szczepanek H. (2006), Badania fokusowe mowy mieszkańców wsi, „Socjolingwistyka” XX, s. 19-35.

Grochola-Szczepanek H. (2007), Wpływ przemian społecznych $i$ kulturowych na mowe mieszkańców wsi (na przykladzie wsi Rzepiska), [w:] Gwary dziś, t. 3. Wewnętrzne zróżnicowanie języka wsi, red. J. Sierociuk, Poznań, s. 167-174.

Grochola-Szczepanek H., 2013, Badania języka mieszkańców wsi w kontekście przemian społecznych, „Socjolingwistyka” XXVII, s. 43-53.

Jelonek T. (2018a), Językowo-kulturowy obraz wsi $i$ jej mieszkańców utrwalony $w$ mikrotoponimach, Kraków.

Jelonek T. (2018b), Słownik mikrotoponimów gminy Wręczyca Wielka, Kraków.

Karaś H. (2015), Zadania dialektologii w zakresie ochrony ginących gwar, „Gwary Dziś”, t. 7, s. $83-95$.

Karaś H. (red.), (2010), Dialekty i gwary polskie. Kompendium internetowe, http://www. dialektologia.uw.edu.pl/index.php?11=opis-dialektow\&12=dialekt-malopolski\&13=dialektmalopolski-wczoraj-i-dzis, 14.09.2020.

Ką́s J. (1999), Socjalno-językowe uwarunkowania rozwoju słownictwa gwarowego, [w:] Collectanea linguistica in honorem Casimiri Polański, red. M. Brzezina, H. Kurek, Kraków, s. $59-64$.

Kąś J. (2001), Metodologia badań leksyki gwarowej w kontekście wspótczesnych przemian kulturowych i spolecznych, [w:] Gwary dziś, t. 1. Metodologia badań, red. J. Sierociuk, Poznań, s. 191-200.

Kąś J., Kurek H. (2001), Język wsi, [w:] Najnowsze dzieje języków słowiańskich. Język polski, red. S. Gajda, Opole, s. 440-459.

Kobus J. (2016), Na ile informator jest wiarygodnym źródtem danych dialektologicznych?, [w:] Zielonogórskie Seminaria Językoznawcze 2015. Kontakty językowe w komunikowaniu, red. M. Steciąg, M. Adamczyk, M. Biszczanik, Zielona Góra, s. 329-338.

Kucała M. (1960), O stownictwie ludzi wyzbywajacych się gwary, „Biuletyn Polskiego Towarzystwa Językoznawczego", z. 19, s. 141-156.

Kucharzyk R. (2001), Gwara w ocenie jej użytkowników, „Język Polski” LXXXI, s. 98-103.

Kucharzyk R. (2002), Język wsi z perspektywy autochtonów, [w:] Dialektologia jako dziedzina językoznawstwa $i$ przedmiot dydaktyki. Księga jubileuszowa dedykowana Profesorowi Karolowi Dejnie, red. S. Gala, Łódź, s. 277-286.

Kucharzyk R. (2012), O potrzebie socjolingwistycznego badania zmian w słownictwie gwarowym, [w:] Języki stowiańskie $w$ ujęciu socjolingwistycznym. Prace przygotowane na XV Międzynarodowy Kongres Slawistów Mińsk 2013, red. H. Kurek, t. 15, Kraków, s. 67-76.

Kurdyła T. (2016), Kilka refleksji o stanie gwar w Polsce potudniowo-wschodniej, [w:] Globalizacja a przemiany języków stowiańskich, red. H. Kurek, M. Święcicka, M. Peplińska, Bydgoszcz, s. 254-264.

Kurek H. (1979), Zasady zapisu tekstów języka mówionego mieszkańców Krakowa, [w:] Wybór tekstów języka mówionego mieszkańców Krakowa, red. B. Dunaj, Kraków, s. 15-16. 
Kurek H. (1994), Zachowania komunikacyjne mieszkańców wspótczesnej wsi, [w:] Kształcenie porozumiewania się. Materiaty konferencji naukowej. Opole 26-28.09.1994 r., red. S. Gajda, J. Nocoń, Opole, s. 109-114.

Kurek H. (1995), Przemiany językowe wsi regionu krośnieńskiego. Studium socjolingwistyczne, Kraków.

Kurek H. (1997), Tradycje badań dialektologicznych a przemiany językowe, [w:] Tradycja badań dialektologicznych w Polsce, red. H. Sędziak, Olsztyn, s. 129-133.

Kurek H. (1998), Przemiany spoleczno-ekonomiczne w Polsce a zmiany językowe, Z Polskich Studiów Slawistycznych, seria 9: Językoznawstwo. Prace na XII międzynarodowy Kongres Slawistów w Krakowie 1998, red. H. Dalewska-Greń, J. Rusek, J. Siatkowski, Warszawa, s. $169-174$.

Kurek H. (2003), Przemiany leksyki gwarowej na Podkarpaciu, Kraków.

Kurek H. (2014), Tożsamość kulturowa polskiej wsi w epoce globalizacji i przemian społeczno-ekonomicznych, [w:] Badania dialektologiczne. Stan, perspektywy, metodologia. Materiaty konferencji naukowej „Gwara i tekst” Kraków, 27-28 września 2013 r., red. M. Rak, K. Sikora, t. 17, Kraków, s. 45-54.

Kurek H. (2018a), Globalizacja a językowo-kulturowe przemiany polskiej wsi, Z Polskich Studiów Slawistycznych", seria 13, t. 2: Językoznawstwo. Prace na XVI Międzynarodowy Kongres Slawistów w Belgradzie 2018, red. Z. Greń, Poznań, s. 155-162.

Kurek H. (2018b), Stownictwo gwarowe w epoce globalizacji, [w:] Historia języka, dialektologia $i$ onomastyka $w$ nowych kontekstach interpretacyjnych, red. R. Przybylska, M. Rak, A. Kwaśnicka-Janowicz, Kraków, s. 203-209.

MAGP (1957-1970), Mały atlas gwar polskich, oprac. przez Pracownię Atlasu i Słownika Gwar Polskich Zakładu Językoznawstwa PAN w Krakowie, t. I-II, kier. K. Nitsch, t. III-XIII kier. M. Karaś, Wrocław.

Ożóg K. (2001), Polszczyzna przełomu XX i XXI wieku. Wybrane zagadnienia, Rzeszów.

Ożóg K. (2007), Konteksty kulturowe wspótczesnej polszczyzny wsi, [w:] Gwary dziś, t. 4. Konteksty dialektologii, red. J. Sierociuk, Poznań, s. 213-220.

Pelcowa H. (1998), Zmiany językowe jako problem badawczy współczesnej dialektologii, [w:] Teoretyczne, badawcze i dydaktyczne założenia dialektologii, red. S. Gala, Łódź, s. $105-117$.

Pelcowa H. (1999), Przeszłość w językowym obrazie świata wspótczesnej wsi, [w:] Przeszłość w językowym obrazie świata, red. A. Pajdzińska, P. Krzyżanowski, Lublin, s. 253-267.

Pelcowa H. (2001), Metodologia badań leksyki gwarowej u schyłku XX wieku, [w:] Gwary dziś, t. 1. Metodologia badań, red. J. Sierociuk, Poznań, s. 183-189.

Pelcowa H. (2002), Dialektologia wobec wyzwań XXI wieku, [w:] Dialektologia jako dziedzina językoznawstwa $i$ przedmiot dydaktyki. Księga jubileuszowa dedykowana Profesorowi Karolowi Dejnie, red. S. Gala, Łódź, s. 383-392.

Pelcowa H. (2009), Trwanie i przemijanie w języku i obyczajowości wiejskiej, [w:] Tradycja w tekstach kultury, red. J. Adamowski, J. Styka, Lublin, s. 89-100.

Pelcowa H. (2011), Tradycja utrwalona w stowach, [w:] Tradycja w kontekstach kulturowych, t. 4, red. J. Adamowski, M. Wójcicka, Lublin, s. 125-132.

Pelcowa H. (2016), Tendencje globalizacyjne w języku i kulturze a koncepcja „małych ojczyzn”, [w:] Globalizacja a przemiany języków stowiańskich, red. H. Kurek, M. Święcicka, M. Peplińska, Bydgoszcz, s. 89-99. 
Pelcowa H. (2019), Zmiany językowe we wspótczesnej wsi (na wybranych przykładach z Lubelszczyzny), [w:] Studia Dialektologiczne V, red. B. Grabka, R. Kucharzyk, A. Tyrpa, Kraków, s. 307-314.

Rejchan J. (1999), Gwary polskie w końcu XX wieku, [w:] Polszczyzna 2000. Orędzie o stanie języka na przełomie tysiącleci, red. W. Pisarek, Kraków, s. 262-278.

Rzetelska-Feleszko E. (1997), Moje doświadczenia dialektologiczne, [w:] Tradycja badań dialektologicznych w Polsce, red. H. Sędziak, Olsztyn, s. 39-43.

Sierociuk J. (2007), Socjologiczny kontekst badań języka mieszkańców wsi, [w:] Gwary dziś, t. 4. Konteksty dialektologii, red. J. Sierociuk, Poznań, s. 325-336.

Stomma L. (1975), Stan badań nad obrzędowościa polska od połowy XVIII w. Czesść I. Analiza statystyczna bazy materiałowej, „Etnografia Polska, t. XIX, z. 1, s. 83-92.

Topolińska Z. (1990), Charakter i dynamika językowych procesów integracyjnych w powojennej Polsce, „Socjolingwistyka” IX, s. 29-35.

Zaręba A. (1955), O metodach i technice badań gwarowych, „Biuletyn Polskiego Towarzystwa Językoznawczego" XIV, s. 140-156.

Ziajka B. (2019), Dialektolog $w$ terenie na tropie nazw o zatartej semantyce. Problemy $i$ wyzwania, [w:] Studia Dialektologiczne V, red. B. Grabka, R. Kucharzyk, A. Tyrpa, Kraków, s. 215-224.

Żebrowska B. (2017), Perspektywy badań ludowego stownego folkloru dziecięcego na przyktadzie gwar okolic Krakowa, [w:] Dynamika rozwoju gwar stowiańskich w XXI wieku, red. D.K. Rembiszewska, Warszawa, s. 235-241. 